\title{
摩擦の分子シミュレーションとエネルギー散逸
}

\author{
碳 津 仁 志 ${ }^{1,2}$ \\ ${ }^{1}$ (株) 豊田中央研究所 寀 480-1192 愛知県長久手市横道 41-1 \\ 2京都大学触媒・電池元素戦略ユニット 焉 615-8520 京都府京都市西京区京都大学桂
}

（2015 年 2 月 3 日受付 ; 2015 年 3 月 23 日掲載決定）

\section{Energy Dissipation Processes Studied by Molecular Simulations of Friction}

\author{
Hitoshi WASHIZU ${ }^{1,2}$ \\ ${ }^{1}$ Toyota Central R \& D Labs., Inc. 41-1 Yokomichi, Nagakute, Aichi 480-1192 \\ ${ }^{2}$ ESICB, Kyoto University, Kyotodaigakukatsura, Nishikyo-ku, Kyoto 615-8520
}

(Received February 3, 2015 ; Accepted March 23, 2015)

\begin{abstract}
Molecular origin of friction is related to the dissipation of the molecular motion energy responses to the external field produced by the sliding motion. Molecular dynamics simulations are suitable method to describe the process. In this article we review a history of molecular dynamics simulation related to tribology and show the "tribo-molecular dynamics" established in 1990s. If the major energy dissipation mode is restricted to the molecular motion in the vicinity of the surface, it is boundary lubrication and fully described by the simulation. In usual case of hydrodynamic lubrication or solid lubrication, however, molecular simulation can not describe the full process due to the large correlation length or low frequency vibration of the system. The understanding of the restriction is important in practical use of the method.
\end{abstract}

KEYWORDS : friction, lubrication, energy dissipation, molecular simulation

\section{1. は じめに}

本稿では, 動摩擦の起源について分子レベルのシミュ レーション技術でいかに探求し得るかについて考えた い。分子シミュレーションは, 狭義には原子単位の分子 動力学法とモンテカルロ法を指し, 広義にはミクロな電 子レベルの計算法あるいはマクロな原子集団の粗視化計 算法も含むが, トライボロジーと最も関連の深い計算手 法は分子動力学法である。これは, ナノスケールにおけ る摩擦の素過程を考えると, 原子の動きを扱う本手法が 最も親和性が高いと思われるからである ${ }^{1)}$.

分子動力学は原子の運動について古典近似を適用した Newton 方程式に基づく計算化学の一解析手法である。 Fig. 1 に, トムソン・ロイター社の Web of Science ${ }^{2)}$ に登 録された「Tribology またはLubrication」かつ「Molecular dynamics」という文字列を表題または要約内に含む 学術論文の数の 5 年ごとの経時変化を示す。「トライボ

E-mail : h@washizu.org
ロジー」あるいは「潤滑」を明示した上での分子動力学 解析は, 1990 年代にはじまり, 1990 年代後半以降に飛 躍的に増加している。これらの研究をトライボ分子動力 学と呼ぶことにする。

さて, 本稿の仮説を提示したい。トライボ分子動力学 の大半の研究は, 意図するせざるにかかわらず, 結果的

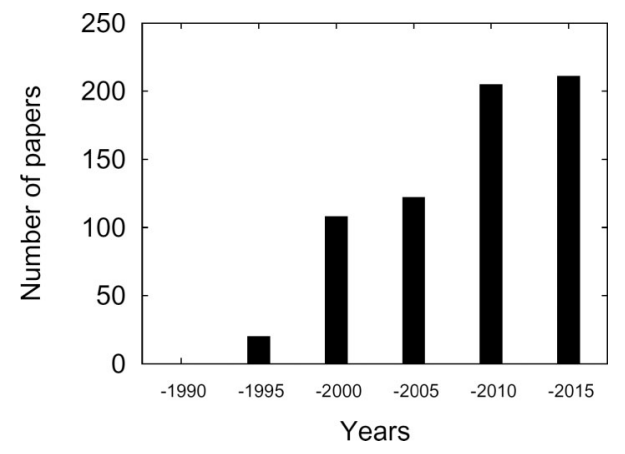

Fig. 1. Number of scientific articles concerning the molecular dynamics in tribology. 
に境界潤滑を扱っているのではないか，ということであ る。ここで境界潤滑とは, 固体表面に液体あるいは気体 の分子が単分子ないし数分子膜程度の厚さに吸着した分 子膜による潤滑である3)。トライボ分子動力学の研究目 的としては，巨視的にみた境界润滑のみならず，流体潤 滑や固体間の摩擦摩耗を扱うことも当然含まれている。 しかしながら, 物質科学の原理原則から考えると, 擬似 的に流体潤滑や固体間の摩擦摩耗を扱うことはできて も, 分子動力学法によるシミュレーションによって, 巨 視的なものと同等の, 通常, トライボロジストが考える 流体潤滑や固体間の摩擦摩耗を扱うことは難しい, とい うことである。その理由を順に考える。

\section{2. トライボ分子動力学以前}

トライボ分子動力学の誕生以前にも, これに梁く関係 する研究は積み重ねられてきた。分子動力学法の起源は 1950 年代後半の Alder らの剛体円盤状原子の計算まで 遡ることができる ${ }^{4)}$ 。当初は, 固体や液体間の構造転移 が主題であったが, 1970 年に同じ著者らによって速度 の自己相関関数に長い記憶効果（ロングテール）が存在 することが示された5)。この相関関数は粘性流体の拡散 係数と関係づけられる。すなわち, 拡散係数や粘性係数 といった統計力学に打ける輸送係数を, 実在の分子につ いて考えるためには, 周囲の分子との運動の長時間の相 関について考慮しなければならないことが示唆された。

これ以降, せん断粘性係数の算出を代表とするバルク の粘性流体のシミュレーションは, 1970 年代, 1980 年 代を通して徐々に整備されてきた非平衡分子動力学の主 要なテーマとなり, 1987 年の Allen \& Tildesley ${ }^{6}$, 1990 年の Evans \& Morriss ${ }^{7}$ の成書にまとめられた。

液体のバルクの粘性の分子論的起源を知ることはトラ イボロジーにとって必要ではあるが, 十分ではない。な ぜなら，トライボロジーは界面科学だからである。1980 年前後から, 固体表面に吸着した液体の平衡構造につい て分子シミュレーションが行われるようになった ${ }^{8)}$ 。吸 着分子の流動性についても議論されたが9), 粘性と絡め て議論されたのは, 1987 年の Bitsanis らの研究であ る ${ }^{10)}$ 。彼らは, 固体壁に挟まれた球状 Lennard-Jones 粒 子による液膜の静的な構造と粘性について, 界面すべり や線形応答理論との関係も含めて議論した。つぎに, 球 状粒子を 20 までつなげた分子内自由度を有する鎖状分 子のせん断下の分子動力学が 1992 年に Thompson らに より行われ ${ }^{11}$, ここに至って, 実質的なトライボ分子動 力学の骨格ができたといって良いであろう。

\section{3. 摩擦とエネルギー散逸}

トライボロジーで扱う摩擦を輸送係数の一種と考える と, 外場が弱い条件に扔いて, 分子運動などに起因する 熱ゆらぎがエネルギー散逸量である輸送係数と関係づけ られる ${ }^{12)}$ 。言い換えると, どのような分子運動のモード が, しゅう動という外場に対して応答するのか, が動摩 擦力の分子論的起源であるといえる。

これを分子動力学による解析に当てはめると, 全原子 モデルによる分子薄膜のせん断のシミュレーションで は, 分子間, 分子内相互作用に起因する様々な緩和モー ドが存在するため, そのどのモードが特徴的に効いてい るかによって摩擦力が変わるといえる。

たとえば，筆者らによる炭化水素系の弾性流体潤滑油 膜の分子動力学によると ${ }^{1,13)}$, 線状分子の主鎖の運動の みであるか，環状分子であったら環反転も考虑すべきか によって, 摩擦挙動が異なることがわかった。この場 合, 熱浴を用いた等温条件でシミュレーションは行うた め, 摩擦によって生じた熱は熱浴に散逸する。

同様の観点から，境界润滑でよく取り上げられる有機 化学吸着膜の摩擦挙動に対しても解析できる。小池らに よる分子動力学解析によると ${ }^{14)}$, 単分子吸着膜の主鎖の 回転運動に起因するエネルギー変化と摩擦力変化とがカ ップルすることが示された。

摩擦によって, 化学結合の生成, 消滅するときにも工 ネルギーは散逸する。たとえば, 表面処理としてょく用 いられる DLC (ダイヤモンドライクカーボン) 表面の 摩擦について, 古典分子動力学に化学結合の組み換えを 導入した REBO (Reacting Empirical Bond Order) 法によ る計算 ${ }^{15)}$ や, 量子分子動力学法 ${ }^{16)}$ な゙゙が使われている。 摩擦に伴う化学反応はトライボ化学反応といわれる。卜 ライボ化学反応に起因する電子励起あるいはフォノン励 起と周辺環境へのエネルギー散逸をカップルして扱うた めには相当な計算化学上の工夫が必要と考えられるが, 現状では系の化学反応を生じない部分における古典力学 的な応力の積算值を摩擦力と見なすことが一般的であ る。この方法でも, 類似の系における摩擦の大小を比較 することは可能である。

Fig. 2 に, 古典分子動力学による酸化鉄同士の摩擦 (a)，およびステアリン酸の吸着した有機化学吸着膜同 士の摩擦（b）のスナップショットを示す。表記のしゅ う動条件に扔いて，(a) は 2.84，（b）は 0.12 の平均摩 擦係数であった。このように, 具体的な数值を得ること は可能であるが, 必ずしも実験と定量的に一致する量で はない。これは, 清浄面における原子間力顕微鏡を用い た精密な実験と比較しても, 原子間相互作用を古典近似 


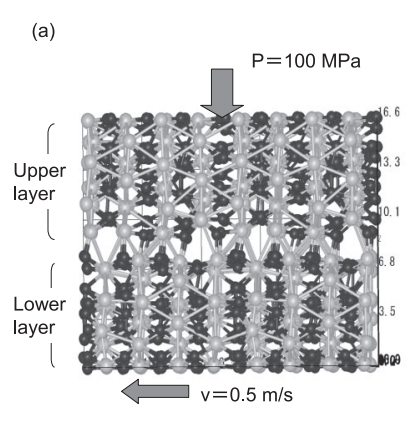

Fig. 2. Schematic pictures of molecular dynamics simulation of friction between iron oxides (a), friction between stearic acid absorbed mono-layers (b).

したことに加え，系外へのフォノン散逸を適切に扱って いないことが主たる原因と考えられる。さらに一般的な 機械工学実験と比較すると, 固体中の格子欠陥や転位の 存在, 実際は多結晶であること, 表面粗さによる実際の 摺動条件との違い, 環境中の水など不純物の混入, とい った様々なミクロおよびマクロ, 物理学的および化学的 な相違点が存在し得る。しかし，ステアリン酸皮膜の生 成による摩擦力の低下は, 極圧剤の作用としてトライボ ロジーでは良く知られて抢り ${ }^{3)}$, 現実的な摩擦剤の設計 指針を得るために分子動力学は十分有用であるといえ る。

以上は, 原子からみて微細な電子状態の変化に伴うエ ネルギー散逸の例であったが, 逆にマクロ側の原子団, たとえば高分子セグメントや層状化合物のシートの単位 で摩擦発現する場合もある。筆者らは, 固体潤滑剤とし て用いられるグラファイトの低摩擦機構として, シート 状グラフェンの熱回避運動機構を粗視化計算により示し

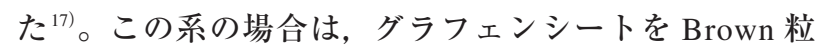
子として粗視化することにより, シート間の構造変化が 摩擦力と関連づけられた。

\section{4. 脱境界潤滑の試み}

前章に挙げた事例は，化学反応の有無や分子モデルの サイズにかかわらず，また対象が固体潤滑，表面処理， 添加剤吸着表面かによらず，トライボ分子動力学を中心 とするトライボロジーの分子シミュレーションでは, 一 般的に表面近傍の特定の分子運動あるいは化学反応に起 因するエネルギー散逸と摩擦との関係を見ている，言い 換えれば境界潤滑を観察しているということを意味して いる。それでは, 現行のトライボ分子動力学あるいはそ の周辺技術によって, 流体潤滑あるいは固体潤滑そのも のを扱うことができるだろうか？ Fig. 3 は，油膜厚さ

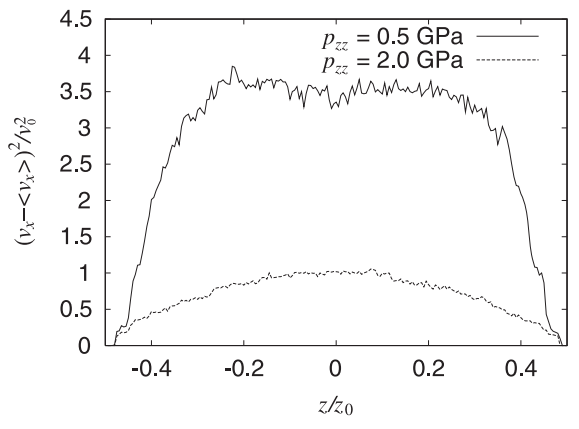

Fig. 3. Profiles of velocity fluctuation at low pressure (solid line, $0.5 \mathrm{GPa}$ ) and at high pressure (dotted line, 2.0 GPa). ${ }^{13)}$

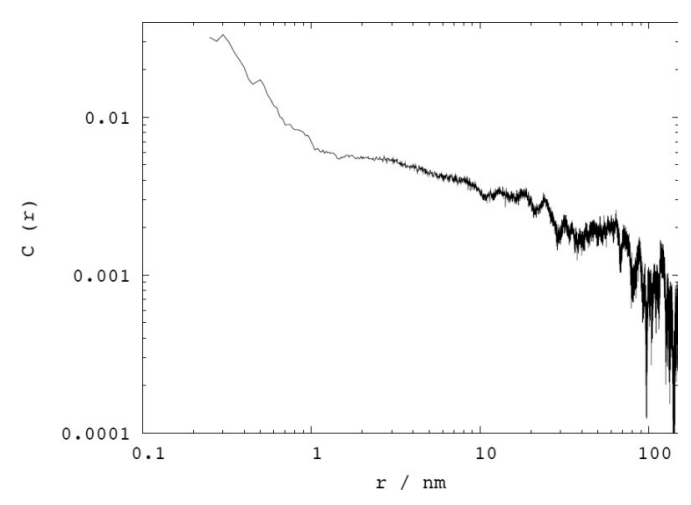

Fig. 4. Momentum correlation function $C(r)$ of the carbon atoms in the vicinity of the wall.

が $10 \mathrm{~nm}$ 程度である $n$-ヘキサンの油膜の分子動力学を

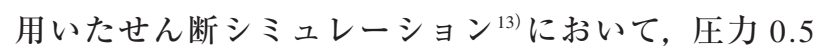
$\mathrm{GPa}$ の低圧, $2.0 \mathrm{GPa}$ の高圧に扔ける油膜厚さ方向の分 子運動のゆらぎを示している。低圧, 高圧の間（1.0 $\mathrm{GPa})$ で摩擦係数が飽和する限界せん断応答を観測して いる。高圧においては, 横軸方向の左右の壁からの分子 運動が抑制されており, その影響が油膜中央付近まで達 しているのがわかる。一方，低圧においては，壁の影響 が $2.5 \mathrm{~nm}$ 程度で収まっており, 中央にバルクの領域が 存在することがわかる。すなわち, 低圧側を流体潤滑状 態と考えれば，単純な分子については $10 \mathrm{~nm}$ 程度以上 の油膜厚さのシミュレーションを行えば分子レベルの潤 滑挙動を扱えることを示している，一方，高圧側を弾性 流体潤滑と考えると, この程度の油膜厚さでは不足であ るといえる。

Fig. 4 は, 弾性流体润滑の圧力 $1 \mathrm{GPa}$, 油膜厚さが一 般的な機械部品の油膜に匹敵する $430 \mathrm{~nm}$ 程度である $n$ ヘキサンの油膜のせん断の大規模分子動力学シミュレー ション ${ }^{18)}$ における, 運動量の対相関関数 $C(r)$ である。 $C(r)$ は壁近傍の分子の運動について, 油膜中央付近に 
(a)

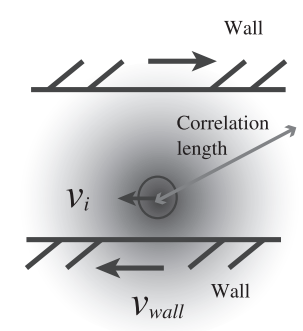

(b)
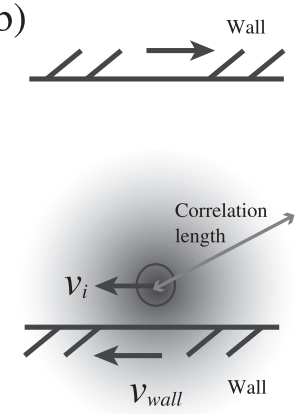

Fig. 5. Schematic illustration of relation between correlation length and the boundary slip for the nano-scale film (a) and the submicron thick film (b).

向かってどの程度の運動が同期しているかについての指 標である。1.5 nm 程度すなわち着目する分子の周囲の 2 3 分子層に対して強い運動の同期が存在し, その外 側に, $80 \mathrm{~nm}$ 程度まで長距離のロングテールがあること がわかる。逆にいうと, このロングテールの存在によっ て, 通常のワークステーションで行われるようなトライ ボ分子動力学では, 薄膜に扔ける界面すべりの発生とい った人工的な問題を含むこととなる（Fig. 5)。粘性は運 動量の対相関関数と関係づけられるが, 運動量相関の及 ぶ領域は基本的に圧力と温度に支配されると考えられ る。油膜厚さが十分でない系（Fig. 5 (a)）では，一方 の壁付近の分子の運動は反対側壁面の運動の影響を受け るが, 現実の機械部品の油膜厚さの系（Fig. 5 (b) ) で は, 反対側壁面の影響を受けないため, 後者においては 界面すべりが生じないと解釈できる。

Fig. 4 に示した例は，ある意味，とても単純に流体潤 滑油膜全体を全原子分子動力学で表現したものといえる が，より洗練された手法としては，マルチスケール計算 がある。安田らは, 系全体は連続体の熱流体力学方程式 に支配され，そのパラメー夕を動的な分子シミュレーシ ヨンにより得るというマルチスケールな計算手法 Synchronized Molecular Dynamics 法を提案した19)。この 手法により粘性発熱による温度上昇といった，ミクロな ダイナミクスに起因するマクロな摩擦発現を議論するこ とが可能となる。また, マクローミクロの接続の仕方に より, 系の空間スケールのみならず時間スケールに関し ても，より現実に近い系を扱うことが可能となる。全原 子分子動力学の欠点としては, すべり方向の不均一性を 取り扱いにくいという点もある。美馬らは, 固体間に挟 まれた液晶分子を Gay-Berne 粒子として粗視化する分子 計算により, 面に水平な方向の長距離秩序があらわれる ことを示した ${ }^{20)}$ このようなマルチスケールおよび粗視

化手法の発展により,すべり方向の, たとえば表面粗さ やテクスチヤの影響も扱えるようになりつつある。

つぎに固体潤滑について考える。固体潤滑とは，基材 表面に低せん断の層状化合物などの固体皮膜を成膜する か, 摺動状態において表面に固体皮膜を化学反応により 生成する分子を添加する技術である。摺動表面にエネル ギー散逸を担う吸着分子などが存在すると, 摩擦力の起 源はその吸着分子の挙動である, ということになるが, これは巨視的にみた境界润滑の素過程である。表面に, 何も介在物が存在せず, 固体の原子列同士が接触する場 合, 膜厚方向に考慮する原子の数が少ない場合は, 人工 的な影響により摩擦力が低く見積もられるということが 梶田らの Green 関数を用いたフォノン散逸のシミュレー ションにより指摘された ${ }^{21)}$ 。最も単純なモデルとして, 二つの固体を正方格子上に配置した質点間の調和振動子 の組であらわし, 平滑かつ整合な表面原子同士の斥力相 互作用のみを仮定した。固体を形成する原子間のバネは 通常硬く, 機械部品の動摩擦現象が生じるすべり速度に おいては固体バルクの原子が集団で応答しなければ，工 ネルギー散逸が生じないためである。必要な原子は, 対 象とする物質や摺動条件によってかわるが, 最大 $1 \mu \mathrm{m}$ 程度であり，すべり方向についても同様であることもわ かってきた22)。これでは通常のトライボ分子動力学で扱 うことは困難であり, やはり手法の工夫が必要となる。

\section{5. を め}

トライボ分子動力学は 1990 年代後半から急速に用い られるようになった。巨視的な対象としての境界潤滑の みならず, 流体潤滑や固体間の摩擦摩耗についても対象 とされるが, 真の流体特性や固体バルクのエネルギー散 逸を扱うためには膨大な原子数の計算が必要となる。す なわち, トライボ分子動力学の大半は結果的に境界潤滑 を扱っているといえるが，このことは，トライボ分子動 力学の有用性を否定するものではない。摩擦現象で対象 とするエネルギー散逸が, どの分子運動や化学反応であ るかについて適切に着目することができれば，擬似的に 弾性流体潤滑や固体間の摩擦摩耗についても扱うことが 可能である。Alder 以来半世紀を経て, 実際のトライボ ロジー上の様々な問題に適用できる時期がきたといえ る。本テーマに関して, 基礎寄り ${ }^{23)}$, 応用寄り ${ }^{24)}$ の学会 誌特集号がそれぞれ筆者らにより編集されたので，ご参 照いただけると幸いである。

\section{謝 辞}

本稿における研究結果の一部は文部科学省最先端・高 性能沉用スーパーコンピュータの開発利用プロジェクト 
次世代ナノ統合シミュレーションソフトウェアの研究開 発において行われた。

\section{文献}

1) 熟津仁志 他 : トライボロジスト 52, 180 (2007).

2) http://ip-science.thomsonreuters.jp/products/web-ofscience/

3) 日本トライボロジー学会編: “トライボロジーハンド ブック”(養賢堂, 2001).

4) B.J. Alder and T.E. Wainwright : J. Chem. Phys. 27, 1208 (1957).

5) B.J. Alder and T.E. Wainwright : Phys. Rev. A 1, 18 (1970).

6) M.P. Allen and D.J. Tildesley : "Computer Simulation of Liquids" (Oxford, 1987).

7) D.J. Evans and G.P. Morriss : "Statistical Mechanics of Nonequilibrium Liquids" 2nd Ed. (Cambridge, 2008).

8) F.F. Abraham : J. Chem. Phys. 68, 3713 (1978).

9) S. Toxvaerd : J. Chem. Phys. 74, 1998 (1981).

10) I. Bitsanis et al. : J. Chem. Phys. 87, 1733 (1987).

11) P.A. Thompson, G.S. Grest and M.O. Robbins : Phys. Rev. Lett. 68, 3448 (1992).

12) 早川禮之助 他 : “非平衡系のダイナミクス入門”, (培
風館, 2006).

13) H. Washizu and T. Ohmori : Lubrication Science 22, 323 (2014).

14) A. Koike and M. Yoneya : Langmuir, 13, 1718 (1997).

15) G.T. Gao, P.T. Mikulski and J.A. Harrison : J. Am. Chem. Soc. 124, 7202 (2002).

16) K. Hayashi et al. : Faraday Discuss. 156, 137 (2012).

17) H. Washizu et al. : Faraday Discuss. 156, 279 (2012).

18) H. Washizu et al. : Tribology Online 9, 45 (2014).

19) S. Yasuda and R. Yamamoto : Phys. Rev. X4, 041011 (2014).

20) T. Mima, T. Narumi, S. Kameoka and K. Yasuoka : Mol. Simul. 34, 761 (2008).

21) S. Kajita, H. Washizu and T. Ohmori : EuroPhys. Lett. 87, 66002 (2009).

22) S. Kajita, H. Washizu and T. Ohmori : Phys. Rev. B 86, 075453 (2012).

23) トライボロジー学会編: 特集/トライボロジーの分 子シミュレーションの新展開, トライボロジスト, 58 (2013).

24) 分子シミュレーション研究会編: 特集/界面のダイ ナミクスー理学から機械工学まで一, 分子シミュレ ーション研究会誌“アンサンブル”17 (2015). 